\title{
LA INCIDENCIA DE LA LABOR DE ESCARIFICADO EN EL AMBIENTE EDÁFICO: CULTIVO DE MAÍZ (ZEA MAYS L.)
}

\author{
Vilche, M. S. ${ }^{1}$; Alzugaray,.$^{1}{ }^{1}$; Montico, S. ${ }^{1}$; DI LeO, N. ${ }^{1}$ \& Falcone, R. ${ }^{1}$
}

\section{RESUMEN}

Se evaluó, en una rotación maíz-soja bajo siembra directa, la condición físico -mecánica, la ocurrencia y distribución de flujos preferenciales, el sistema de raíces y materia seca a la cosecha del cultivo de maíz, en un Argiudol vértico (Zavalla, S. Fe). Se escarificó un lote con 14 años de siembra directa en agosto de 2005 y a los 45 días se sembró maíz. Los tratamientos: siembra directa sin escarificar (SD) y siembra directa escarificada (SDE). El aflojamiento provocado por el paratill favoreció el movimiento del agua como flujos preferenciales (FP), indujo una exploración radical más temprana de los horizontes subsuperficiales y una mayor producción de materia seca. Esto destaca el rol de la fractura en el movimiento del agua, aun después de 10 meses de haber sido efectuada la labor. El patrón de humedecimiento en SD reveló una circulación relacionada con la red de macroporos vinculada a la actividad biológica.

Palabras clave: labor profunda, siembra directa, flujos preferenciales, maíz.

\section{SUMMARY}

The impact of the scarifier in the soil environment: Maize (Zea mays L.)

In a corn-soybean rotation under no tillage, the physical and mechanical condition, the occurrence and distribution of preferential flow, the root system and dry matter at harvest of maize crop were evaluated in a vertic Argiudol (Zavalla, S. Fe). Tillage with paratill took place in a plot with 14 years with no tillage in 2005 and after 45 days the maize was seeded. The treatments were no tillage without scarified (NT) and no tillage scarified (SNT). The loosening caused by paratill favored the movement of water as preferential flow (PF), induced an early radical exploration of subsurface horizons and greater dry matter production. PF emphasize the roll of the fracture in the movement of the water, even after ten months of having been made the work. The pattern of wetting in NT revealed a network-related movement of macropores linked to biological activity

Key words: deep tillage, no tillage, preferential flow, maize.

1.- Facultad de Ciencias Agrarias (UNR). Campo Experimental Villarino. C.C. 14. (S2125ZAA) Zavalla, provincia de Santa Fe. Tel. (0341) 970080.Email: marizovilche@yahoo.com.ar

Manuscrito recibido el 25 de agosto de 2010 y aceptado para su publicación el 10 de noviembre de 2010. 